\title{
The effect of holding time after Sr addition on microstructural and mechanical properties of A356 alloy
}

\author{
Sr ilavesinden sonra bekletme süresinin A356 alaşımının mikroyapısal ve \\ mekanik özelliklerine etkisi
}

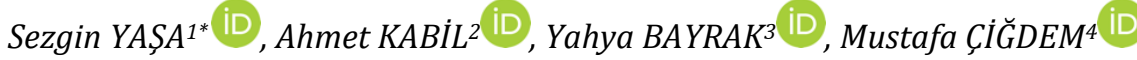

1,2,3,4 Department of Metallurgical and Materials Engineering, Faculty of Chemical and Metallurgical Engineering,

Yildiz Technical University, İstanbul, Turkey.

sezgin.yasa92@gmail.com, kabilahmet@gmail.com, bayraky@yildiz.edu.tr, cigdem@yildiz.edu.tr

Received/Gelis Tarihi: 17.01.2019

Revision/Düzeltme Tarihi: 18.11.2019

doi: $10.5505 /$ pajes.2020.04557

Accepted/Kabul Tarihi: 06.01.2020 Research Article/Araștırma Makalesi

\begin{abstract}
The spheroidization of the silicon eutectic phase in aluminum is an important parameter for casting and significantly influences the material properties. Sr has been used for a long time for eutectic modification in aluminum and many researches have been made on this subject. In this study, the effect of holding time after Sr addition on the mechanical properties and eutectic phase modification of the aluminum were investigated. $200 \mathrm{ppm} \mathrm{Sr}$ was chosen as the amount of Sr and the holding times were chosen as 20,40 and 80 minutes. Tensile test was performed for the determination of mechanical properties and ultimate tensile strength and percentage of elongation values were measured. In order to quantify eutectic modification, the length / width (aspect ratio) ratios of eutectic silicon particles were measured. In addition, Bifilm Index of the molten metal was determined with the reduced pressure test (RPT). With the increase in the holding time, an increase in the aspect ratio and in the Bifilm Index was measured. It has been observed that the tensile strength and elongation values have decreased as the holding time has increased.
\end{abstract}

Keywords: Eutectic modification, Sr, A356, Bifilm index.

\section{Introduction}

The use of aluminum alloys in technical use is quite common and especially $\mathrm{Al}-\mathrm{Si}$ alloys are popular among them [1]. Al-Si$\mathrm{Mg}$ alloys have advantages such as decent mechanical properties, good corrosion resistance and castability. A356 alloy is used in the automotive industry and in some critical applications [2]-[4]. In addition, the demand for improved fuel efficiency and weight reduction has increased the use of aluminum alloys in the aerospace and automotive industries [5]. Mechanical and microstructural properties are very important for these applications.

The mechanical properties of aluminum alloys are determined by microstructural components for instance secondary dendrite arm spacing (SDAS), intermetallic compounds, porosity and eutectic phases.

Eutectic modification in these alloys is done by adding elements such as $\mathrm{Na}, \mathrm{Sb}$ and $\mathrm{Sr}$ to the molten metal in the form of master alloys. Recently, Sr has become the most commonly used refining agent because of its good modification ratio and low fading effect. Sr modification enhances the mechanical properties of aluminum alloy by refining eutectic silicon phase from plate to a fine morphology [6].

\begin{abstract}
Öz
Alüminyumdaki silisyum ötektik fazının küreselleșmesi, döküm için önemli bir parametredir ve malzeme özelliklerini önemli ölçüde etkiler. $\mathrm{Sr}$ alüminyumda ötektik modifikasyon için uzun süredir kullanılmaktadır ve bu konuda birçok araștırma yapılmıștır. Bu çalışmada $\mathrm{Sr}$ ilavesinden sonra bekletme süresinin alüminyumun mekanik özelliklerine ve ötektik faz modifikasyonuna etkisi incelenmistir. Modifikasyon için 200 ppm Sr, bekletme süreleri ise 20, 40 ve $80 \mathrm{dk}$. olarak seçilmiştir. Mekanik özelliklerin tespiti için çekme testi yapılarak çekme dayanımı ve uzama değerleri ölçülmüștür Ötektik modifikasyonu ölçmek için, ötektik silisyum partiküllerinin boy/en oranları ölçülmüstür. Ek olarak, sıvı metalin Bifilm indeksi vakum altında katılaştırma testi (VAK) ile ölçülmüştür. Bekleme süresindeki artısla birlikte, en boy oranında ve Bifilm indeksinde artıs gözlenmiștir. Cekme dayanımı ve uzama değerlerinin ise tutma süresi arttıkça azaldığı gözlenmiștir.
\end{abstract}

Anahtar kelimeler: Ötektik modifikasyon, Sr, A356, Bifilm indeksi.

\footnotetext{
${ }^{*}$ Corresponding author/Yazışılan Yazar
}

It is well known that the plate-like eutectic Si phase have detrimental effect on the mechanical properties of $\mathrm{Al}-\mathrm{Si}$ cast alloys especially for the ductility. In order to improve the strength and ductility of Al-Si cast alloys, plate-like Si has to be converted to a finer and sphere-like shape. Eutectic modification has been a long-standing research topic since 1921 [7]. A lot of study has been done on eutectic modification in aluminum alloys [8]-[11]. In these studies, researchers investigated the effects of $\mathrm{Sr}$ amount and holding time on the eutectic modification.

One of the major factors that adversely affect the quality of the liquid metal and hence the mechanical properties is the presence of double oxides (bifilms) in the liquid metal. Bifilms are formed as a result of folding of the oxide layer on the surface of liquid aluminum during mold filling. As the solubility of the hydrogen dissolved in the liquid decreases during solidification, the bifilms in the liquid metal forms suitable areas for nucleation of the hydrogen. By means of the reduce pressure test (RPT), the gas pressure of the nucleated hydrogen exceeds the hydrostatic pressure of the liquid metal, thus opening the bifilms. Bifilm index is a method used to quantify liquid metal quality. In this method, after the liquid metal is solidified under vacuum, the total length of the pores in the 
cross section is calculated with the help of image analysis program. This total length is called as bifilm index [12],[13].

$$
\text { Bifilm Index }=\sum \text { (Pore length) }
$$

In this study, effect of holding time after $\mathrm{Sr}$ addition on microstructural and mechanical properties of A356 alloy has been investigated.

\section{Experimental methods}

The primary A356 alloy ingots were used in the experiments. The chemical analysis of the alloy was determined with using optical emission spectrometer and composition of the alloy was given in the Table 1.

Table 1: Chemical analysis of A356 alloy /wt-\%.

\begin{tabular}{ccccccc}
\hline $\mathrm{Si}$ & $\mathrm{Mg}$ & $\mathrm{Fe}$ & $\mathrm{Ti}$ & $\mathrm{Mn}$ & $\mathrm{Cu}$ & $\mathrm{Al}$ \\
\hline 7.5 & 0.4 & 0.15 & 0.11 & 0.03 & 0.002 & Bal. \\
\hline
\end{tabular}

Ingots were melted with an electric resistance furnace in $\mathrm{SiC}$ crucible. Then, the molten aluminum was poured to a metal mold at $730{ }^{\circ} \mathrm{C}$ shown in Figure 1.

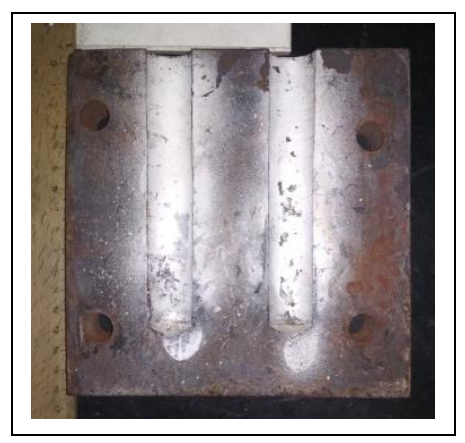

Figure 1. Metal mold.

Metal mold was pre-heated to a $400{ }^{\circ} \mathrm{C}$ before castings. AlSr 10 master alloy was added to the melt, so that the melted alloy had $200 \mathrm{ppm}$ Sr by weight. After addition of the master alloy, the liquid was gently stirred with the metal rod for 30 seconds. The melt was placed back into the furnace after mixing and castings were made by applying three different holding times; 20,40 and 80 minutes.

Two $120 \mathrm{~mm}$ length and $20 \mathrm{~mm}$ diameter specimens were produced from each casting. One of these specimens was machined to dimensions as shown in the Figure 2 for tensile test and the tests were performed on the samples with the universal tensile test device.

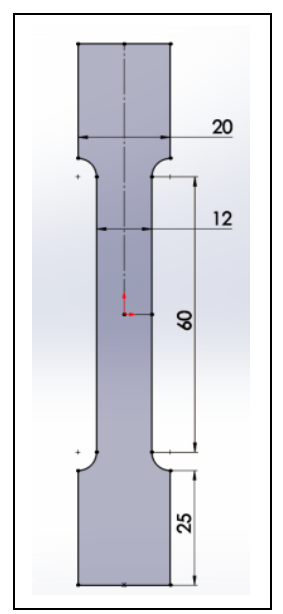

Figure 2. Tensile specimen dimensions (mm).
The other cast sample was cut from the $2 \mathrm{~cm}$ above the bottom. After grinding and fine polishing, the internal structure of the sample was examined with a metal microscope.

The aspect ratios of the eutectic particles were measured on the images with x500 magnification with the help of Imagej image processing program. These images were given in the Figure 4.

The reduced pressure test (RPT) is used extensively in the literature to determine the Bifilm index of the molten metal. Test apparatus is shown in the Figure 3. A sample to measure Bifilm index was cast to a RPT device and vacuum applied. After solidification, sample was cut in a half and grind with a 600 grid paper. RPT specimens are shown in the Figure 6. The Bifilm Index measurements are done with the help of Imagej program.

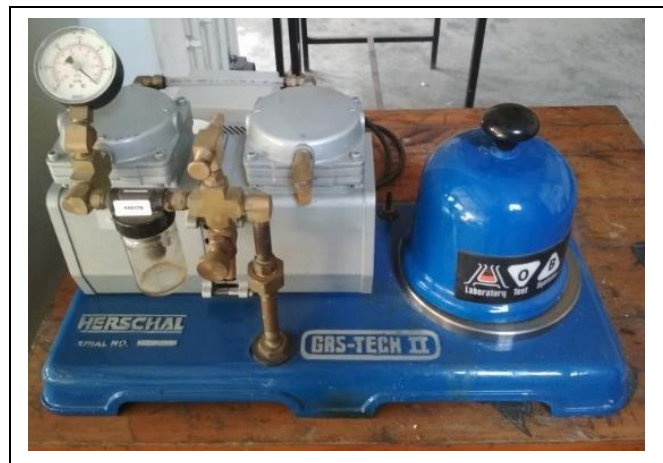

Figure 3. RPT device.

\section{Results and discussion}

Figure 4 shows the microstructure images of as cast specimens with different holding times after addition of $200 \mathrm{ppm}$ Sr. From the microstructure images it can be seen that as the holding time increases, the modification rate decreases and therefore, the Si eutectic phase changes from fine fibrous to a coarse plates.

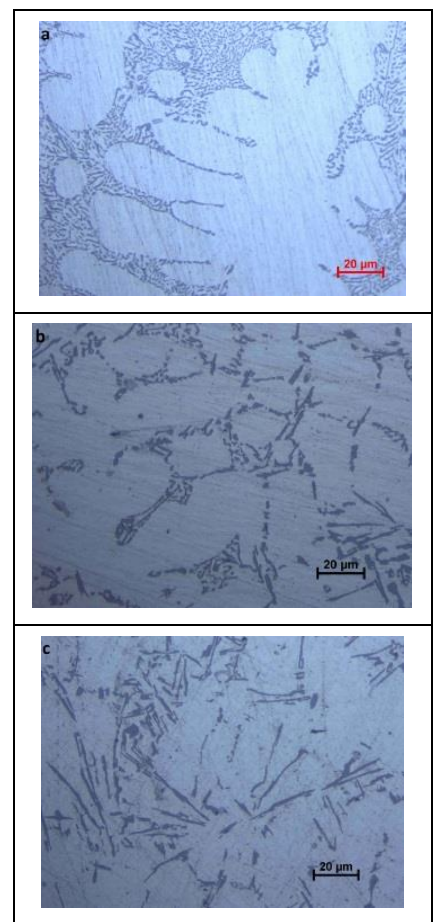

Figure 4. Microstructures of samples x500. (a): 20 minutes, (b): 40 minutes, (c): 80 minutes). 
It is clear from the images in Figure 4 that the eutectic modification is the lowest at 80 min holding time. It was proved by the study of J H Zhang et al [10] that Sr amount in the melt decreased with increasing holding time and accordingly the modification rate decreased.

The length/width ratio (aspect ratio) is one of the methods used to measure the eutectic modification rate in Al-Si alloys. From the images in Figure 4, aspect ratios of eutectic particles were measured and the results are shown in Figure 5.

According to these results, while aspect ratio of the eutectic particles in the holding time of 20 minutes was 2.97 , with the increase in holding time, the aspect ratio was increased to 7.07 at 40 min and 15.12 at 80 minutes.

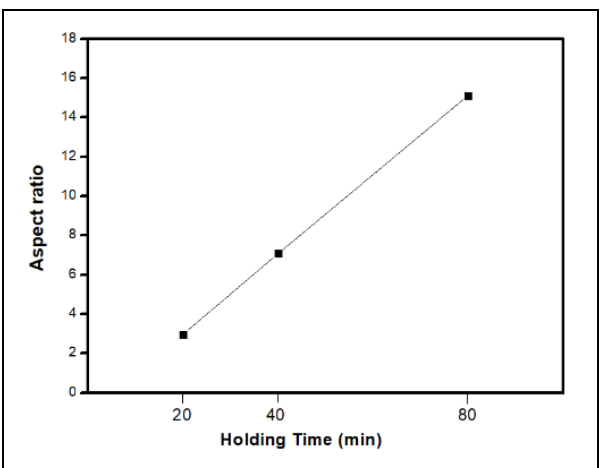

Figure 5. Aspect ratio of eutectic particles in different holding times.

Figure 6 shows cross-sections of RPT samples of castings. The Bifilm Index of the liquid metal was determined with the help of image analysis software.
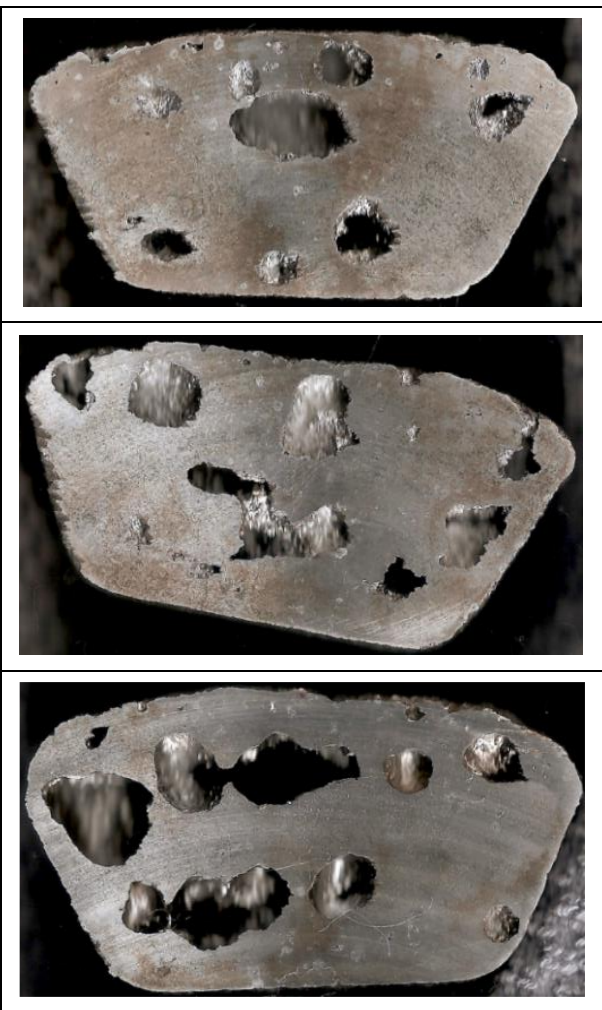

Figure 6. RPT specimens of the castings with holding time of; $20 \mathrm{~min}$ (top), $40 \mathrm{~min}$ (middle) and $80 \mathrm{~min}$ (bottom).
It was observed that Bifilm Index increased with increasing holding time after adding $\mathrm{Sr}$ (Figure 7). The main reason for this situation is thought to be increased oxidation rate of aluminum caused by Sr addition [14].

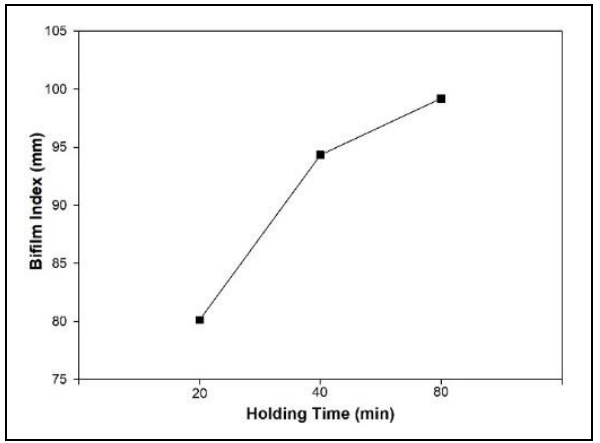

Figure 7. Increase in the Bifilm Index with increasing holding time.

Figure 8 and Figure 9 show the ultimate tensile strength and \% elongation results respectively. As can be seen from the bifilm index results, the amount of bifilm and the aspect ratio of the eutectic phase are minimized during the 20 minutes holding period. Therefore, UTS and\% elongation values are higher than others.

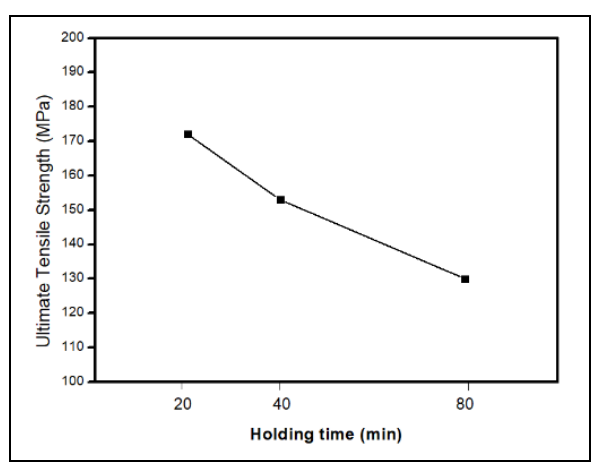

Figure 8. Change in the ultimate tensile strength with holding time.

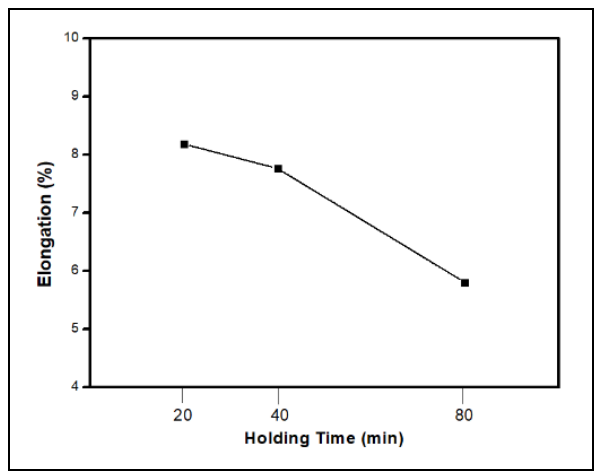

Figure 9. Change in the \% elongation with holding time.

The presence and amount of bifilm is known to have a negative effect on mechanical properties. With the increase of the holding time, it was observed that the tensile strength and \% elongation decreased due to the increase in the Bifilm index and the decrease in the rate of eutectic modification [15].

\section{Conclusions}

1. Modification of eutectic silicon could be achieved with 200 ppm Sr on 20 minutes holding time, 
2. As the holding time increase, amount of Bifilm index are found to increase,

3. With the increase on holding time, it is observed that the eutectic structure change from the fine fibrous to the coarse plate like,

4. The increase in Bifilm index and the increase in the aspect ratio of eutectic particles decrease the tensile strength and \% elongation.

\section{References}

[1] Rzadkosz S, Zych J, Piękoś M, Kozana J, Garbacz-Klempka A. "influence of refining treatments on the properties of AlSi alloys". Metalurgija, 54(1), 35-38, 2015.

[2] Campbell J. Complete Casting Handbook: Metal Casting Processes. $1^{\text {st }}$ ed. Oxford, UK, Elsevier Ltd, 2011.

[3] Chirita G, Stefanescu I, Soares D, Silva FS. "Influence of vibration on the solidification behaviour and tensile properties of an Al-18wt\%Si alloy". Materials \& Design, 30(5), 1575-1580, 2009.

[4] Bozchaloei GE, Varahram N, Davami P, Kim SK. "Effect of oxide bifilms on the mechanical properties of cast Al-7Si$0.3 \mathrm{Mg}$ alloy and the roll of runner height after filter on their formation". Materials Science and Engineering $A$, 548, 99-105, 2012.

[5] Raiszadeh R, Griffiths WD. "The behaviour of double oxide film defects in liquid al alloys under atmospheric and reduced pressures". Journal of Alloys and Compounds, 491(1-2), 575-580, 2010.

[6] Zamani M, Seifeddine S. "Determination of pptimum Sr level for eutectic si modification in Al-Si cast alloys using thermal analysis and tensile properties". International Journal of Metalcasting, 10(4), 457-465, 2016.
[7] Xu C, Wang F, Mudassar H, Wang C, Hanada S, Xiao W, Ma C. "Effect of Sc and Sr on the eutectic Si morphology and tensile properties of Al-Si-Mg alloy". Journal of Materials Engineering and Performance, 26(4), 1605-1613, 2017.

[8] Samuel AM, Garza-Elizondo GH, Doty HW, Samuel FH. "Role of modification and melt thermal treatment processes on the microstructure and tensile properties of Al-Si alloys". Materials \& Design, 80, 99-108, 2015.

[9] Uludag M, Cetin R, Dispinar D, Tiryakioglu M. "Characterization of the effect of melt treatments on melt quality in Al-7wt\%Si-Mg alloys". Metals, 157(7), 1-16, 2017.

[10] Zhang J H, Xing SM, Han QY, Guo Q, Wang RF. "Effect of Sr additive amount and holding time on microstructure of A390 aluminum alloy". $4^{\text {th }}$ AMMSE, Tianjin, China, 22-24 September, 2017.

[11] Derin S, Aybarç U, Birol Y. "Optimization of strontium addition for the modification of AlSi7Mg0.3 alloy". $18^{\text {th }}$ International Metallurgy and Material Congress, Istanbul, Turkey, 29 September-01 October 2016.

[12] Dispinar D, Campbell J. "Use of bifilm index as an assessment of liquid metal quality". International Journal of Cast Metals Research, 19(1), 5-17, 2013.

[13] Dispinar D, Campbell J. "Porosity, hydrogen and bifilm content in al alloy castings". Materials Science and Engineering A, 528(10-11), 3860-3865, 2011.

[14] Miresmaeili SM. "Effect of Strontium on the oxidation behavior of liquid Al-7Si alloys". Oxidation of Metals, 71(1-2), 107-123, 2009.

[15] Dispinar D, Akhtar S, Nordmark A, Di Sabatino M, Arnberg L. "Degassing, hydrogen and porosity phenomena in A356". Materials Science and Engineering A, 527(16-17), 3719-3725, 2010. 